Ethos: Jurnal Penelitian dan Pengabdian kepada Masyarakat, Vol 9, No.1, Januari 2021: 79-88

\title{
PROGRAM KETAPEL ASI DI PUSKESMAS KARANGDORO KOTA SEMARANG
}

\author{
${ }^{1}$ Rachma Purwanti, ${ }^{2}$ Agavita Cendy, ${ }^{3}$ Raisa Namira, ${ }^{4}$ Azzahra K., ${ }^{5}$ Permata Laila \\ K., ${ }^{6}$ Mar Atus Sholihah \\ 1,3,4,5,6 Departemen Ilmu Gizi, Universitas Diponegoro, Jawa Tengah, Indonesia \\ ${ }^{2}$ Puskesmas Karangdoro, Jawa Tengah, Indonesia \\ *Email: rachmapurwanti@fk.undip.ac.id
}

\begin{abstract}
Exclusive breastfeeding was important for under 6-month-old children because an essential component from breast milk cant be changed by commercial formulas. Exclusive breastfeeding practices influenced by predisposing, enabling, and reinforcing factors. KETAPEL ASI (Konseling, Edukasi dan Pelatihan ASI Eksklusif dan ASI Perah) program at Karangdoro Community Health Center, Semarang City had goals to increase mother knowledge about exclusive breastfeeding, to increase skills about breastfeeding by pumping, and growing commitment to exclusive breastfeeding practices. This community development was held in December 2019. Participants were mothers of $<6$-month-old children. Screening, education, and training to increase skills about breast milk pumping and counseling about breastfeeding practices use 3 locations: Melati Baru Integrated service pos (Posyandu), Kemijen Integrated service pos (Posyandu), and Karangdoro Community Health Centers. Monitoring and evaluation did by visiting the subject home, doing interviews, and observation. Results of KETAPEL ASI program such there were increasing of mother knowledge, practices, and commitment about exclusive breastfeeding that showed by increasing of knowledge score pre-test post-test from 81 - 94 point, and there were 5 subjects had practices breastfeeding by pumping and commit to gives exclusive breastfeeding for their child until 6 months old. Our suggestion: there were sustain education about storage time of pumped breastmilk, and management of breast milk pumped, increase enabling and reinforcing factors from their family and health professional to motivate mothers to practices exclusive breastfeeding and also giving lactation facility to working mother.

Keywords: exclusive breastfeeding, breast milk pumped, management of breast milk pumped, nutrition knowledge
\end{abstract}

\begin{abstract}
Abstrak: Pemberian ASI eksklusif sangat penting bagi anak usia kurang dari enam bulan karena kandungan ASI tidak dapat digantikan oleh susu formula komersial. Pemberian ASI eksklusif dipengaruhi oleh faktor predisposisi, faktor pendukung, dan faktor penguat. Program KETAPEL ASI (Konseling, Edukasi dan Pelatihan ASI Eksklusif dan ASI Perah) di Puskesmas Karangdoro Kota Semarang bertujuan untuk meningkatkan pengetahuan ibu terkait ASI Eksklusif, meningkatkan keterampilan ibu terkait cara memerah ASI, dan menanamkan komitmen melaksanakan ASI Eksklusif. Program pengabdian kepada masyarakat ini dilaksanakan pada bulan Desember Tahun 2019. Peserta program adalah ibu bayi < 6 bulan. Skrining subjek, edukasi ASI Eksklusif dan ASI perah, pelatihan memerah ASI, dan konseling dilaksanakan di 3 tempat yaitu di Posyandu Melati Baru, Posyandu Kemijen, dan di Puskesmas Karangdoro, Kota Semarang. Monitoring dan evaluasi program dilaksanakan dengan mengunjungi rumah subjek dan melakukan wawancara serta observasi. Hasil dari program KETAPEL ASI yaitu adanya peningkatan pengetahuan, praktik, dan komitmen dari ibu menyususi yang ditunjukkan dengan peningkatan skor pengetahuan ibu setelah dilakukan penyuluhan dibandingkan skor sebelum dilakukan penyuluhan (rata-rata meningkat dari skor 81 menjadi 94), dan sebanyak 5 ibu menyusui yang telah menerapkan ASI Eksklusif dan ASI Perah serta berkomitmen untuk tetap terus memberikan ASI secara eksklusif sampai bayi berusia 6 bulan.
\end{abstract}


Diharapkan adanya edukasi lebih lanjut mengenai umur simpan ASI perah dan manajemen ASI perah, dukungan dari keluarga (suami dan anggota keluarga lainnya) dan dukungan tenaga kesehatan berupa pemberian motivasi kepada ibu untuk terus menyusui secara eksklusif, serta fasilitas untuk ibu menyusui di tempat kerja dan tempat-tempat umum untuk meningkatkan pemberian ASI eksklusif.

Kata Kunci: ASI eksklusif, ASI perah, manajemen ASI perah, pengetahuan gizi

\section{Pendahuluan}

Air Susu Ibu (ASI) merupakan zat gizi yang paling ideal untuk bayi, karena kandungan gizinya yang sesuai dengan kebutuhan bayi dan juga mengandung antibodi untuk bayi (Fahriani et al., 2014). Pemberian ASI eksklusif sangat penting bagi anak usia kurang dari enam bulan, kandungan ASI tidak dapat digantikan oleh susu formula komersial. Pengenalan makanan selain ASI seperti jus, suplemen, makanan bertekstur lembut, semi padat dan padat bagi anak usia kurang dari enam bulan dapat berakibat buruk kedepannya (X \& DW, 2012). Balita yang tidak mendapat ASI eksklusif lebih berisiko mengalami penyakit infeksi, terutama diare (Nur \& Marissa, 2014). Diare juga dapat mengakibatkan balita mengalami kurang gizi, kehilangan elektrolit tubuh, malabsorpsi zat gizi dan gangguan pertumbuhan serta stunting pada anak (Keusch et al., 2013).

Pemberian ASI eksklusif sangat bermanfaat bagi bayi, antara lain meningkatkan pertumbuhan dan perkembangan bayi, melindungi bayi dari paparan penyakit infeksi bakteri, virus, jamur dan parasit, mengandung komposisi yang tepat bagi kebutuhan bayi, meningkatkan kecerdasan bayi, dan mencegah terserang penyakit tidak menular saat dewasa. Selain memiliki manfaat untuk bayi, ASI eksklusif juga memberikan manfaat bagi ibu antara lain, sebagai alat kontrasepsi alami, menjaga kesehatan ibu, mengurangi risiko kanker payudara, dan meningkatkan ikatan batin pada ibu dan anak (Yusrina \& S.R., 2016).

Faktor-faktor yang dapat mempengaruhi keberhasilan pemberian ASI eksklusif antara lain usia ibu $\geq 25$ tahun, kesehatan ibu, psikis dan keyakinan ibu terhadap produksi dan pemberian ASI eksklusif, tingkat pendidikan, pengetahuan dan paparan informasi ibu mengenai ASI eksklusif, status ekonomi, adanya dukungan keluarga untuk pemberian ASI eksklusif dan konseling mengenai pentingnya ASI eksklusif dari petugas kesehatan (Leong, 2009; Heather et al., 2009; Al-Sahab B, Tamim H, Mumtaz G, Khawaja G, Khogali M, Afifi R, 2008; Butler S, Williams M, Tukuitonga C, 2004). Kadangkala dalam proses pemberian ASI eksklusif dijumpai beberapa hambatan seperti informasi yang salah mengenai payudara akan turun jika menyusui, ASI hanya keluar sedikit, dan ibu bekerja (Yusrina \& S.R., 2016).

Berdasarkan data hasil pelaporan puskesmas seluruh Kota Semarang pada tahun 2018, pemberian ASI eksklusif pada bayi usia 0 -6bulan sebesar $68,22 \%$ dengan total bayi 10.733 bayi. Data tersebut telah memenuhi renstra cakupan pemberian ASI Eksklusif Kota Semarang 65,20\% dan renstra DKK Kota Semarang 65\%. Namun, pada kenyataannya data cakupan pemberian ASI Eksklusif di Puskesmas Karangdoro masih terbilang rendah, pada Tahun 2018 cakupan ASI Eksklusif sebesar $31 \%$ dan cakupan ASI Eksklusif pada 2019 selama 6 bulan terakhir juga masih rendah, yakni $\pm 41,65 \%$ (Juni $21,21 \%$, Juli 53,85\%, Agustus 25\%, September 
69,57\%, Oktober 37,04\%, dan November 43,24\%). Kementerian Kesehatan Republik Indonesia pun menetapkan cakupan pemberian ASI eksklusif menurut standar pelayanan minimal (SPM) nasional melalui Keputusan Menteri Kesehatan RI No.1457/MENKES/SK/X/2003 tentang Standar Pelayanan Minimal Kesehatan di Kabupaten/Kota menargetkan 80\% bayi mendapatkan ASI eksklusif. Oleh karena itu, dapat dikatakan bahwa cakupan pemberian ASI eksklusif di Kota Semarang maupun Puskesmas Karangdoro belum memenuhi target nasional (Dinas Kesehatan Kota Semarang, 2018; Karangdoro, 2019; Kementerian Kesehatan RI, 2003). Berdasarkan uraian di atas, penulis melaksanakan program KETAPEL ASI (Konseling, Edukasi dan Pelatihan ASI Eksklusif dan ASI Perah) di Puskesmas Karangdoro Kota Semarang. Program dilaksanakan dengan tujuan:

a. Meningkatkan pengetahuan ibu terkait ASI Eksklusif.

b. Meningkatkan keterampilan ibu terkait cara memerah ASI.

c. Ibu mampu berkomitmen melaksanakan ASI Eksklusif.

\section{Metode}

Program KETAPEL ASI (Konseling, Edukasi dan Pelatihan ASI Eksklusif dan ASI Perah) ditujukan kepada ibu menyusui yang masih memberikan ASI kepada bayi usia di bawah 6 bulan. Program dilaksanakan selama bulan Desember 2019. Skrining subjek, edukasi ASI Eksklusif dan ASI perah, pelatihan memerah ASI, dan konseling dilaksanakan di 3 tempat yaitu di Posyandu Melati Baru, Posyandu Kemijen, dan di Puskesmas Karangdoro, Kota Semarang. Monitoring dan evaluasi program dilaksanakan dengan mengunjungi rumah subjek dan melakukan wawancara serta observasi.
Program ini dilakukan secara personal kepada kelompok sasaran dengan tahap awal berupa penjaringan bayi yang masih diberi ASI melalui form checklist saat kegiatan posyandu dan imunisasi berlangsung. Program KETAPEL ASI merupakan pelatihan terkait ASI Eksklusif pada ibu bayi berusia kurang dari 6 bulan yang masih diberikan ASI walaupun sudah dikombinasi dengan MPASI ataupun susu formula. Program dilaksanakan kepada 10 subjek dengan permasalahan ASI eksklusif.

Program KETAPEL ASI dilakukan dengan metode edukasi, demonstrasi, dan konseling secara personal sesuai permasalahan yang dialami masing-masing individu. Materi edukasi yang diberikan berupa pentingnya ASI Eksklusif, tatalakasana ASI Perah, dan penyajian ASI Perah dengan metode diskusi dan tanya jawab. Media yang digunakan yaitu leaflet. Konseling dilakukan untuk mengajak ibu agar mau berkomitmen tetap memberikan ASI eksklusif setelah program dilakukan. Metode yang digunakan adalah Problem solving dan sharing terkait masalah yang dihadapi secara personal. Demonstrasi cara memerah ASI dilakukan dengan memutarkan video dan praktik memerah ASI dengan media Mannequin. Monitoring dilakukan dengan mengunjungi rumah responden. Kegiatan ini bertujuan untuk mengobservasi keterampilan ibu dalam memerah dan menyajikan ASI setelah dilaksanakannya edukasi, pelatihan, dan konseling saat intervensi berlangsung.

\section{Hasil dan Pembahasan}

Karakteristik peserta program ditampilkan dalam tabel 1. Berdasarkan tabel 1 diketahui bahwa sebagian besar ibu (90\%) berpendidikan menengah (SMP/SMA). Terdapat 50\% ibu yang bekerja di luar rumah dan $50 \%$ lainnya 
merupakan ibu rumah tangga. Penelitian lain melaporkan bahwa pendidikan orang tua berhubungan dengan gizi anak. Orangtua yang hanya menempuh pendidikan primer cenderung kurang memperhatikan gizi pada anaknya (Alderman \& Headey, 2017). Penelitian lain juga mengungkap bahwa praktik pemberian ASI eksklusif lebih baik pada orang tua yang menempuh pendidikan lebih dari 12 tahun disbanding orang tua dengan pendidikan kurang dari 12 tahun (Zhao et al., 2017; Habibi et al., 2018). Subjek dalam penelitian ini seluruhnya termasuk dalam kategori menempuh pendidikan $\leq 12$ tahun.

Laporan penelitian terdahulu menjelaskan bahwa status ibu rumah tangga berhubungan dengan pemberian ASI eksklusif selama 6 bulan $(\mathrm{AOR}=2,69)$, selain variabel-variabel lainnya yaitu besar keluarga, dan kunjungan ante - post natal (Panigrahi \& Sharma, 2019). Penelitian lain juga melaporkan hasil yang sejalan bahwa status pekerjaan ibu berhubungan negatif dengan pemberian ASI eksklusif pada bayi hingga usia 6 bulan (Rahmawati, 2010; Habibi et al., 2018).

Sebagian besar (70\%) bayi berusia 2 bulan dan sebagian besar berstatus gizi normal berdasarkan indikator BB/TB. Hasil ini menunjukkan bahwa bayi belum mengalami growth faltering meskipun beberapa diantaranya sudah diberikan susu formula.

Tabel 1. Karakteristik ibu dan bayi

\begin{tabular}{llll}
\hline $\begin{array}{l}\text { Karakteristik ibu } \\
\text { dan bayi }\end{array}$ & Kategori & $\mathrm{n}$ & $\%$ \\
\hline $\begin{array}{l}\text { Pendidikan } \\
\text { terakhir ibu }\end{array}$ & SD & 4 & 40 \\
\cline { 2 - 4 } & SMP & 1 & 10 \\
\cline { 2 - 4 } & SMA & 5 & 50 \\
\hline Pekerjaan ibu & Bekerja & 5 & 50 \\
\cline { 2 - 4 } & $\begin{array}{l}\text { Tidak } \\
\text { bekerja }\end{array}$ & 5 & 50 \\
\hline Usia bayi & 1 bulan & 2 & 20 \\
\cline { 2 - 4 } & 2 bulan & 7 & 70 \\
\cline { 2 - 4 } & 3 bulan & 1 & 10 \\
\hline $\begin{array}{l}\text { Status gizi bayi } \\
\text { (BB/TB) }\end{array}$ & Kurus & 1 & 10 \\
\hline & Normal & 9 & 90 \\
\hline
\end{tabular}

\section{a. Kegiatan Edukasi dan konseling ASI eksklusif}

Edukasi dilaksanakan secara personal kepada 10 subjek. Edukasi diawali pre-test dan diakhiri dengan post-test. Pre-test dilakukan untuk mengetahui tingkat pengetahuan ibu terkait ASI eksklusif dan ASI perah, selanjutnya ibu diberikan edukasi konseling. Hal ini dilakukan berdasarkan laporan penelitian terdahulu bahwa terdapat hubungan yang signifikan antara pendidikan ibu, pekerjaan ibu, pengetahuan ibu, sikap ibu, peran petugas, keterpaparan media, peran suami, peran orang tua dengan pemberian ASI eksklusif (Astuti, 2013).

Pengetahuan (knowledge), sikap (attitude) dan tindakan (practice) merupakan tahapan perubahan perilaku atau pembentukan perilaku. Sebelum seseorang mengadopsi perilaku (perilaku baru) ia harus tahu terlebih dahulu apa arti atau manfaat perilaku tersebut bagi dirinya (Notoatmodjo, 2012). Oleh karena itu, edukasi dan konseling merupakan kegiatan utama yang dipilih dalam Program KETAPEL ASI ini.

Edukasi dan konseling yang diberikan dalam program KETAPEL ASI meliputi informasi tentang pentingnya ASI eksklusif (kandungan ASI, jenis ASI, teknik, dan waktu pemberian ASI) dan pelaksanaan pemberian ASI perah (cara memerah, menyimpan, dan menyajikan). Edukasi dilakukan untuk meningkatkan pengetahuan ibu dengan media berupa leaflet. Konseling dilakukan untuk mengajak ibu agar mau berkomitmen tetap memberikan ASI eksklusif setelah program dilakukan. Selanjutnya, ibu diminta untuk menjawab soal post-test. 
Tabel 2. Hasil pre-test dan post-test pengetahuan subjek tentang ASI

\begin{tabular}{ccc}
\hline Subjek ke- & Skor pre-test & Skor post-test \\
\hline 1 & 90 & 90 \\
\hline 2 & 80 & 90 \\
\hline 3 & 80 & 90 \\
\hline 4 & 80 & 100 \\
\hline 5 & 60 & 90 \\
\hline 6 & 100 & 100 \\
\hline 7 & 80 & 100 \\
\hline 8 & 90 & 100 \\
\hline 9 & 100 & 100 \\
\hline 10 & 50 & 80 \\
\hline $\begin{array}{c}\text { Rata-rata } \\
\text { skor }\end{array}$ & 81 & 94 \\
\hline
\end{tabular}

Berdasarkan tabel 2, diketahui rata-rata nilai pre-test subjek sebesar 81 dan rata-rata nilai post-test sebesar 94. Skor pengetahuan pre-test subjek tergolong kurang jika nilai berada di bawah rata-rata skor total seluruh subjek. Sebagian besar subjek berpengetahuan kurang (60\% subjek). Setelah dilakukan edukasi dan konseling, 5 subjek (50\%) mengalami peningkatan skor pengetahuan (skor post-test $>81$ (rerata skor pre-test) sedangkan 1 subjek (10\%) mengalami peningkatan skor, namun skornya masih $<81$. Setelah dilakukan post-test kedua, terjadi penurunan skor pengetahuan pada 3 responden $(75 \%)$, dan 1 responden (25\%) tidak mengalami perubahan skor pengetahuan.

Pengetahuan dan sikap positif merupakan faktor predisposisi yang berhubungan dengan pemberian ASI eksklusif. Faktor penguat yang berhubungan dengan pemberian ASI eksklusif yaitu dukungan keluarga, dukungan atasan, dan dukungan teman kerja. Faktor yang paling dominan berhubungan dengan pemberian ASI eksklusif adalah pengetahuan (Septiani et al., 2017). Adanya peningkatan skor pengetahuan termasuk dalam faktor predisposisi untuk meningkatkan pemberian ASI eksklusif. Peningkatan pengetahuan merupakan tahap awal dalam upaya adopsi perilaku baru yaitu pemberian ASI secara eksklusif sampai bayi berusia 6 bulan.
Peningkatan skor pengetahuan dalam program ini dikarenakan informasi seputar ASI eksklusif yang disampaikan saat edukasi telah terserap dengan baik oleh subjek peserta program. Peserta program memberikan respon yang baik dan berkonsentrasi saat diberikan edukasi. Peserta program pun aktif bertanya apabila kurang memahami informasi yang disampaikan. Namun, daya ingat dan kesibukan membuat beberapa subjek tidak dapat mengingat beberapa informasi yang telah disampaikan sebelumnya, hal ini dibuktikan dengan hasil post-test lanjutan yang dilaksanakan 2 hari setelah edukasi dilaksanakan, sebanyak 3 subjek mengalami penurunan skor pengetahuan.

Konseling dalam program ini menghasilkan komitmen para ibu untuk tetap memberikan ASI eksklusif atau berusaha kembali memberikan ASI secara eksklusif meskipun sebelumnya sudah memberikan ASI dan kombinasi dengan susu formula. Hal ini diharapkan dapat lebih mengoptimalkan program ASI eksklusif untuk status gizi bayi yang optimal pula. Sebagaimana penelitianpenelitian sebelumnya melaporkan bahwa konseling pada ibu balita dapat meningkatkan pengetahuan dan sikap ibu terkait gizi. (Sofiyana \& Noer, 2013; Pratiwi \& Bahar, 2016)

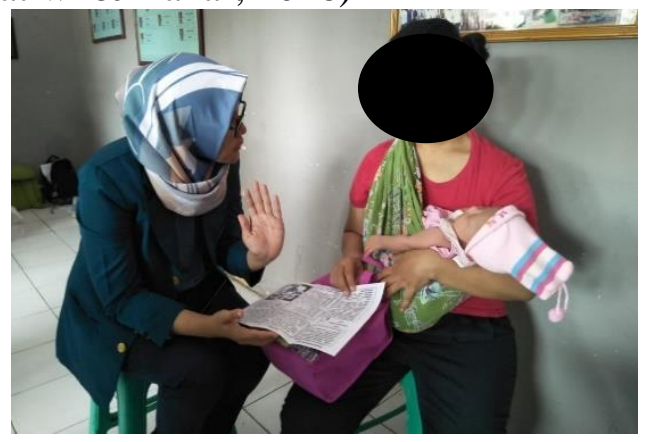

Gambar 1. Edukasi dan konseling dengan Ny. Ni 


\section{b. Kegiatan demonstrasi ASI perah}

Pelatihan keterampilan memerah ASI dibantu dengan alat peraga berupa mannequin (boneka) payudara. Selanjutnya ibu menyusui diminta untuk memeragakan kembali cara memerah ASI, setelah memeragakan cara memerah ASI. Sebelumnya, responden diwawancara untuk mengetahui bagaimana praktik pemberian ASI eksklusif sebelum terpapar oleh program ini.

Tabel 3. Data keterampilan memerah ASI sebelum-setelah demonstrasi ASI perah dilaksanakan

\begin{tabular}{lcccc}
\hline Keterampilan & \multicolumn{2}{c}{ Sebelum } & \multicolumn{2}{c}{ Setelah } \\
\cline { 2 - 5 } memerah ASI & $\mathrm{n}$ & $\%$ & $\mathrm{n}$ & $\%$ \\
\hline Bisa & 5 & 50 & 10 & 100 \\
\hline Tidak & 5 & 50 & 0 & 0 \\
\hline total & 10 & 100 & 10 & 100 \\
\hline \multicolumn{2}{r}{ Berdasarkan } & \multicolumn{2}{c}{ tabel } & 3,
\end{tabular}

keterampilan subjek dalam memerah ASI meningkat setelah demonstrasi dilakukan. Setelah diberikan pelatihan dengan metode demonstrasi dan penayangan video terkait pemerahan ASI, 10 responden dapat mendemonstrasikan pemerahan ASI dengan benar. Keberhasilan ini dikarenakan adanya pelatihan pemerahan ASI dan demonstrasi kegiatan dilaksanakan yang dilakukan secara personal.

Tabel 4. Data praktik ASI eksklusif sebelum-setelah program KETAPEL ASI dilaksanakan

\begin{tabular}{llcccc}
\hline \multirow{2}{*}{ No } & \multirow{2}{*}{ Indikator } & \multicolumn{2}{c}{ Sebelum } & \multicolumn{2}{c}{ Setelah } \\
\cline { 3 - 6 } & & $\mathrm{n}$ & $\%$ & $\mathrm{n}$ & $\%$ \\
\hline 1 & ASI eksklusif & & & & \\
\hline & Ya & 4 & 40 & 5 & 50 \\
\hline & Tidak & 6 & 60 & 5 & 50 \\
\hline 2 & Menyimpan & & & & \\
& ASI perah & & & & \\
\hline & Bisa & 6 & 60 & 10 & 100 \\
\hline & Tidak & 4 & 40 & 0 & 0 \\
\hline 3 & Menyajikan & & & & \\
& ASI perah & & & & \\
\hline & Bisa & 5 & 50 & 10 & 100 \\
\hline & Tidak & 5 & 50 & 0 & 0 \\
\hline
\end{tabular}

Berdasarkan tabel 4, diketahui bahwa Ibu yang bisa memerah ASI 5 orang (50\%), yang bisa menyimpan ASI Perah 6 orang $(60 \%)$ dan yang bisa menyajikan ASI Perah 5 orang (50\%) dan total ibu yang melaksanakan ASI Eksklusif 4 orang (40\%). Setelah program dilaksanakan, semua ibu sudah dapat memerah, menyimpan dan menyajikan ASI Perah. Total ibu yang melaksanakan ASI Eksklusif setelah program dilaksanakan sebanyak 5 orang $(50 \%)$. Adapun 5 orang (50\%) lainnya belum bisa memberikan ASI eksklusif.

Gagalnya pemberian ASI Eksklusif dapat terjadi karena faktor ibu bekerja (karena kurangnya masa cuti, lamanya jam kerja, serta kelelahan fisik yang dialami oleh ibu) (Desmond \& Meaney, 2016). Dari 10 subjek, 5 subjek merupakan ibu bekerja namun hanya 2 orang yang memberikan ASI Eksklusif. Selain karena faktor ibu bekerja, fasilitas laktasi di tempat kerja yang kurang memadai juga menjadi salah satu faktor yang menghambat praktik ASI eksklusif (ibu memilih untuk menyambung ASI dengan susu formula, selain itu juga responden tidak terbiasa memerah ASI.

\section{c. Monitoring kegiatan dan konseling lanjutan}

Setelah melaksanakan edukasi, konseling, dan demonstrasi selanjutnya dilakukan proses monitoring. Monitoring hanya dilakukan pada 4 orang subjek karena terdapat beberapa kendala seperti subjek tidak berkenan untuk ditemui dan sulit menyesuaikan waktu dengan subjek. Dari 4 orang subjek yang dikunjungi, 2 diantaranya sudah mampu melakukan ASI Perah yaitu Ny. Ua dan Ny. Ye. Hal ini menunjukkan perilaku baru telah mulai terbentuk. Sebagaimana teori yang dikemukakan oleh para ahli bahwa perubahan perilaku dimulai dari pengetahuan dan sikap yang positif 
terhadap perilaku baru, kemudian berlanjut pada tindakan/aksi perilaku yang baru tersebut.

Dua responden yang masih belum mencapai target yang diharapkan, dikarenakan terdapat beberapa kendala yang berasal dari faktor internal dan eksternal responden. Faktor internal berupa kesehatan ibu, psikis dan keyakinan ibu terhadap produksi dan pemberian asi eksklusif, sedangkan faktor eksternal berupa pengetahuan dan paparan informasi ibu mengenai ASI eksklusif, ibu bekerja, adanya dukungan keluarga untuk pemberian ASI eksklusif (Leong, 2009; Heather et al., 2009; AlSahab B, Tamim H, Mumtaz G, Khawaja G, Khogali M, Afifi R, 2008; Butler S, Williams M, Tukuitonga C, 2004).

Masalah kesehatan ibu yang dialami berupa payudara bengkak terjadi pada Ny. Se, hal tersebut terjadi karena adanya kesalahan dalam memerah ASI. Payudara yang bengkak disebabkan ASI yang tidak dapat keluar, sedangkan volume ASI semakin bertambah yang menyebabkan payudara terasa sakit. Selain itu juga disebabkan oleh posisi pelekatan bayi yang tidak tepat. Hal tersebut sesuai dengan penelitian yang berjudul teknik menyusui, posisi, perlekatan, dan keefektifan menghisapstudi pada ibu menyusui di RSUD Sidoarjo, terdapat $22,1 \%$ ibu yang mengalami masalah payudara akibat kesalahan posisi dalam menyusui bayi. Masalah payudara terjadi pada ibu yang perlekatan tidak benar (Anjarsari, P., Rinata, E., dan Rusdiyati, 2016). Akibatnya responden lebih memilih memberikan susu formula pada bayinya. Konseling mengenai posisi perlekatan bayi dan cara memerah yang benar sudah diberikan pada responden, namun rasa trauma akibat payudara bengkak menyebabkan responden masih belum memiliki kemauan dan memilih untuk memberikan susu formulanya ketika bepergian. Hasil post-test kedua yang diberikan kepada Ny. Se diketahui terdapat penurunan 1 poin dari post-test sebelumnya menjadi 80. Adanya penurunan skor disebabkan saat melakukan kunjungan ibu tidak dapat fokus untuk menjawab soal yang diberikan, karena anak sedang rewel dan terus menangis saat melihat orang yang baru dikenal. Sehingga, beliau tidak dapat fokus saat ditanyai perihal umur simpan ASI dan pemberian kembali ASI yang tidak dihabiskan.

Masalah yang ditemui selanjutnya adalah keyakinan ibu terhadap produksi dan pemberian ASI Eksklusif dialami oleh $\mathrm{Ny}$. Ni. Responden merasa produksi ASInya hanya sedikit dan takut tidak dapat mencukupi kebutuhan bayinya, terlebih responden juga bekerja, sehingga memilih untuk memberikan susu formula untuk mencukupi kebutuhan bayinya. Responden memiliki riwayat ASI tidak keluar pada anak pertama dan kedua sehingga memilih untuk memberikan susu formula, begitu juga pada anak ketiganya walaupun ASInya sudah keluar meskipun sedikit. Intervensi yang diberikan berupa edukasi terkait cara perlekatan dan memotivasi Ny. Ni untuk terus memerah dan mengingatkan beliau bahwa produksi ASI sesuai dengan pengeluaran ASI. Saat melakukan kunjungan ke rumah $\mathrm{Ny}$. Ni belum mencoba memerah dan masih menggunakan susu formula karena masih merasa ASI yang dikeluarkan belum mencukupi kebutuhan anaknya. Hasil post-test kedua diketahui bahwa nilai pengetahuan $\mathrm{Ny}$. $\mathrm{Ni}$ turun sebesar 1 point, dari post-test pertama. ${ }^{30}$ Penurunan skor pengetahuan pada Ny. Ni dikarenakan beliau lupa pada poin umur simpan ASI Perah dan pemberian kembali ASI Perah yang sebelumnya tidak dihabiskan oleh bayi. Dua orang subjek yang sudah mencapai target yang diharapkan, memiliki beberapa kendala 
baik internal dan eksternal subjek. Namun, kendala yang dialami oleh kedua subjek tersebut dapat dihadapi dengan niat, motivasi dan edukasi saat pelaksanaan intervensi.

Masalah yang dialami oleh $\mathrm{Ny}$. Ye, yaitu volume ASI yang keluar sedikit. Hal ini berdampak pada kondisi bayi yang mengalami hiperbilirubinemia sehingga mendapatkan fototerapi, dan ibu disarankan untuk memberikan susu formula oleh bidan yang menangani persalinan. Bayi dengan asupan ASI Eksklusif yang kurang dapat mengalami hiperbilirubinemia. ${ }^{31}$ Kebiasaan tersebut berlanjut hingga usia 2 bulan namun pemberian susu formula diberikan hanya saat ibu sedang bepergian. Setelah dilakukan penggalian informasi secara mendalam, diketahui bahwa saat ini produksi ASI Ny. Ye sudah lancar. Hal ini dibuktikan ketika sedang menyusui, salah satu payudara lainnya juga mengeluarkan ASI. Produksi ASI yang banyak ini, belum bisa dimanfaatkan oleh Ny. Ye dengan maksimal. Karena ASI yang keluar dari payudara lainnya tidak ditampung dan disimpan untuk digunakan saat bepergian dan $\mathrm{Ny}$. Ye lebih memilih untuk menggunakan susu formula. Intervensi yang dilakukan pada $\mathrm{Ny}$. Ye adalah memberikan informasi bahwa ASI yang keluar selama menyusui sebaiknya ditampung, serta cara menyimpan, menyajikan, dan cara memerah ASI sehingga Ny. Ye tidak perlu memberikan susu formula selama berpergian. Informasi diterima dengan baik dan telah diterapkan oleh Ny. Ye. Hal ini dibuktikan dengan adanya ASI Perah di lemari pendingin dan $\mathrm{Ny}$. Ye dapat mempraktikan cara memerah ASI dengan benar, serta pengakuan Ny. Ye yang saat ini sudah tidak memberikan susu formula pada saat berpergian. Pada saat kunjungan ke rumah $\mathrm{Ny}$. Ye dilakukan post test ulang dengan soal yang sama dan diperoleh hasil nilai $\mathrm{Ny}$. Ye turun 1 point dari post test pertama.
Adanya penurunan skor pengetahuan Ny. Ye, yang diketahui melalui penuturan beliau lupa mengenai umur simpan ASI yang tepat.

Masalah yang dialami oleh Ny. Ua adalah kurang keyakinan terkait produksi ASI. Ny. Ua adalah pegawai pabrik yang masih cuti, sehingga masih memberikan ASI Eksklusif secara langsung pada bayinya. Ny. Ua juga sudah bisa memerah ASI dan sudah mulai mempersiapkan stok ASI Perah untuk persiapan saat $\mathrm{Ny}$. Ua sudah mulai bekerja. Pada saat dilakukan wawancara, Ny. Ua berencana untuk menyambung ASI dengan susu formula ketika sudah mulai bekerja, karena takut hasil perahan ASI tidak mencukupi kebutuhan bayinya, karena menurut penuturan beliau bayinya minum ASI dalam jumlah yang banyak. Selain itu Ny. Ua juga menuturkan bahwa di tempat kerja beliau belum tersedia ruang laktasi dan lemari pendingin untuk menyimpan ASI, namun hal tersebut tidak menghalangi niat beliau untuk tetap memerah ASI karena Ny. Ua sudah mempunyai cooler bag. Intervensi yang diberikan pada Ny. Ua adalah memberikan edukasi bahwa ASI yang diperah sudah cukup untuk memenuhi kebutuhan bayi tanpa tambahan susu formula. Edukasi juga diberikan terkait cara penyimpanan ASI yang benar dan masa simpan ASI untuk meyakinkan $\mathrm{Ny}$. Ua untuk terus memerah dan menambah stok ASI. Konseling diberikan pada Ny. Ua yaitu rekomitmen untuk terus memberikan ASI Eksklusif dan mengingatkan beliau bahwa produksi ASI sesuai dengan pengeluaran ASI. ${ }^{30}$ Hasil kunjungan rumah menunjukan bahwa Ny. Ua sudah memiliki banyak stok ASI dan menuturkan akan memberikan ASI Eksklusif walaupun sudah kembali bekerja. Hasil post test ke $2 \mathrm{Ny}$. Ua menunjukan bahwa nilai beliau tidak turun dibandingkan nilai post test pertama. 


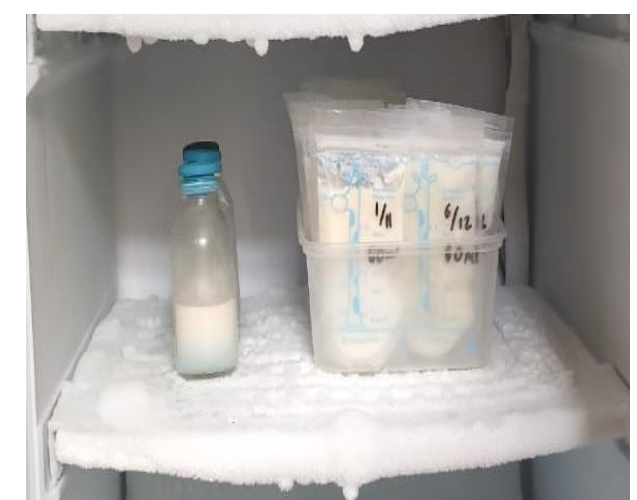

Gambar 2. ASI perah Ny Ua

\section{Kesimpulan dan Saran}

Setelah program KETAPEL ASI selesai dilaksanakan terdapat perubahan pengetahuan, praktik, dan komitmen dari ibu menyususi yaitu : terjadinya peningkatan skor pengetahuan ibu setelah dilakukan penyuluhan dibandingkan skor sebelum dilakukan penyuluhan (rata-rata meningkat dari skor 81 menjadi 94), sebanyak 5 ibu menyusui yang telah menerapkan ASI Eksklusif dan ASI Perah dan berkomitmen untuk tetap terus memberikan ASI secara eksklusif sampai bayi berusia 6 bulan.

Saran berkaitan dengan program KETAPEL ASI yaitu bahwa prak tik pemberian ASI eksklusif pada responden dapat lebih dioptimalkan dengan adanya

1. Edukasi lebih lanjut mengenai umur simpan ASI perah dan manajemen ASI perah,

2. Dukungan dari keluarga (suami dan anggota keluarga lainnya) dan dukungan tenaga kesehatan berupa pemberian motivasi kepada ibu untuk terus menyusui secara eksklusif, serta

3. Fasilitas untuk ibu menyusui di tempat kerja dan tempat-tempat umum.

\section{DAFTAR PUSTAKA}

Al-Sahab B, Tamim H, Mumtaz G, Khawaja G, Khogali M, Afifi R D, 2008. Predictors of breastfeeding in a developing country: result of a prospective cohort study. Pub Health Nutr, 12, pp.1350-6.

Alderman H \& Headey DD, 2017. How important is parental education for child nutrition. World Development, 94, pp.448-464.

Anjarsari, P., Rinata, E., dan Rusdiyati E, 2016. Teknik menyusui, posisi, perlekatan dan keefetifan menghisap - Studi pada ibu menyusui di RSUP Sidoarjo. In Rakernas AIPKEMA. pp. 128-139.

Astuti I, 2013. Determinan Pemberian ASI Eksklusif Pada Ibu Menyusui. Jurnal Health Quality, 4(1), pp.6068.

Butler S, Williams M, Tukuitonga C PC, 2004. Factor associated with not breastfeeding exclussively among mothers of a cohort of pacific infants in New Zealand. J New Zealand Med Ass, 117, pp.1-10.

Desmond D \& Meaney S, 2016. A Qualitative study investigating the barriers to returning to work for brestfeeding mothers in Irland. International Breastfeeding Journal, pp.11-16.

Dinas Kesehatan Kota Semarang, 2018. Profil Kesehatan Kota Semarang 2018 ,

Fahriani R, Rohsiswatno R \& Hendarto A, 2014. Faktor yang Memengaruhi Pemberian ASI Eksklusif pada Bayi Cukup Bulan yang Dilakukan Inisiasi Menyusu Dini (IMD). Sari Pediatri, 15(6), pp.394-402.

Habibi M, Laamiri FZ, Aguenaou H, Doukkali L, Mrabet M \& Barkat A, 2018. The impact of maternal sociodemographic characteristics on breastfeeding knowledge and practices: an experience from 
Casablanca, Morocco. International Journal od Pediatrics and Adolescence Medicine, (5), pp.3948.

Heather L, Hc K \& Ct. S, 2009. Risk factor for cessation of breastfeeding prior to six months postpartum among a community sampel of woman in Calgary, Alberta. Can J of Pub Health, 68, pp.1-4.

Karangdoro P, 2019. Data cakupan ASI Eksklusif di wilayah kerja Puskesmas Karangdoro Kota Semarang,

Kementerian Kesehatan RI, 2003. Keputusan Menteri Kesehatan RI No.1457/MENKES/SK/X/2003 tentang Standar Pelayanan Minimal Kesehatan di Kabupaten/Kota,

Keusch G, Rosenberg I \& Denno D, 2013. Implications of acquired environmental enteric dysfunction for growth and stunting in infants and children living in low- and middleincome countries. Review: Food and Nutrition Bulletin, 34, pp.357-364.

Leong T, 2009. Knowledge, attitude and practice on breastfeeding in Klang, Malaysia. Int Malay J, 8, pp.17-21.

Notoatmodjo S, 2012. Promosi Kesehatan dan Perilaku Kesehatan, Jakarta: Rineka Cipta.

Nur A \& Marissa N, 2014. Riwayat pemberian air susu ibu dengan penyakit infeksi pada balita. Jurnal Kesehatan Masyarakat Nasional, 9, pp.144-149.

Panigrahi A \& Sharma D, 2019. Exclusive breastfeeding practice and its determinants among mother of children aged 6 - 12 months living in slum areas of Bhubaneswar, eastern India. Clinical Epidemiology and Global Health, (7), pp.424-428.

Pratiwi H \& Bahar H, 2016. Peningkatan pengetahuan, sikap, dan tindakan ibu dalam upaya pencegahan gizi buruk pada balita melalui metode konseling gizi di wilayah kerja Puskesmas Wua-wua Kota Kendari Tahun 2016. Jurnal Ilmiah Mahasiswa Kesehatan Masyarakat, 1(3), pp.1-8.

Rahmawati MD, 2010. Faktor-faktor yang mempengaruhi pemberian ASI eksklusif pada ibu menyusui di Kelurahan Pedalangan Kecamatan Banyumanik, Kota Semarang. Jurnal KesMaDaSka, 1(1), pp.8-17.

Septiani H, Budi A \& Karbito, 2017. Faktor-Faktor yang Berhubungan dengan Pemberian ASI Eksklusif Oleh Ibu Menyusui yang Bekerja Sebagai Tenaga Kesehatan. AISYAH: Jurnal Ilmu Kesehatan, 2(2), pp.159-174.

Sofiyana D \& Noer ER, 2013. Perbedaan pengetahuan, sikap dan perilaku ibu sebelum dan setelah konseling gizi pada balita gizi buruk. Journal of Nutrition College, 2(1), pp.134-144.

X C \& DW WTB, 2012. Global trends in exclusive breastfeeding. International Breastfeeding Journal, pp.7-12.

Yusrina A \& S.R. D, 2016. Faktor yang mempengaruhi niat ibu memberikan ASI eksklusif di Kelurahan Megarsari, Sidoarjo. Jurnal Promosi Kesehatan, 4(1), pp.11-21.

Zhao J, Zhao Y, Du M, Binns CW, Curtin J \& Lee AH, 2017. Maternal education and breastfeeding practices in China: a systematic review and meta-analysis. Midwifery, 50, pp.62-71. 